\title{
Tuning the catalytic performance of carbon nanotubes by tuning the conjugation between the $\pi$ orbitals of carbon nanotubes and the active oxygenic functional groups
}

\author{
DU Yujue, LI Zhenhua \#, FAN Kangnian* \\ Shanghai Key Laboratory of Molecular Catalysis and Innovative Materials, Department of Chemistry, Fudan University, Shanghai 200433, China
}

A R T I C L E I N F O

\section{Article history:}

Received 30 April 2013

Accepted 23 May 2013

Published 20 July 2013

\section{Keywords:}

Carbon nanotube catalyst

Propane

Oxidative dehydrogenation

Density functional theory

Conjugation effect

\begin{abstract}
A B S T R A C T
Periodic density functional theory calculations were used to systematically investigate the origin of the catalytic activity of carbon nanotubes (CNTs) and ways to improve the catalytic performance of CNTs for the oxidative dehydrogenation of propane. Detailed characterizations of the geometric and electronic structure of the active oxygenic functional groups (CO groups) were presented. The results reveal that the catalytic performance of CNTs can be tuned by tuning the conjugation between CNT $\pi$ orbitals and the orbitals of the active CO groups. Through conjugation, CNTs act as an electron reservoir to donate or accept electrons from the $\mathrm{CO}$ group. We found that $\mathrm{CO}$ groups with a negative charge have higher $\mathrm{C}-\mathrm{H}$ bond activation activity but lead to a more stable $i$-propoxide intermediate, which inhibits the formation of propene, while positively charged CO groups have the opposite effect. The balance between the activities of the two $\mathrm{C}-\mathrm{H}$ activation steps can be obtained by tuning the charge of the $\mathrm{CO}$ group. This study increases the understanding of the origin of the activity of CNT catalysts at the microscopic scale and gives guidance for the preparation of high-performance CNT catalysts.
\end{abstract}

(C) 2013, Dalian Institute of Chemical Physics, Chinese Academy of Sciences. Published by Elsevier B.V. All rights reserved.
The oxidative dehydrogenation $(\mathrm{ODH})$ reaction of light alkanes can be used to generate various light alkenes for use as intermediates in the synthesis of synthetic rubbers, plastics and a number of industrially important chemicals [1,2]. The use of metal or metal oxide systems as traditional heterogeneous catalysts for these reactions is unfavourable because of the high cost of noble metals and the detrimental environmental effects caused by undesirable by-products such as $\mathrm{CO}_{2} / \mathrm{CO}[3,4]$. Carbon nanomaterials are commonly used in catalysis, especially in the ODH of saturated hydrocarbon molecules [5,6]. As one of the most important carbon materials, carbon nanotubes (CNTs) have shown potential for a wide range of applications in cata- lytic reactions because of their high specific surface areas, chemical and electrochemical inertness, and easy surface modification [4]. Zhang and Su et al. [5,7,8] showed that partially oxidized CNTs efficiently catalyze the ODH of low active $n$-butane and ethylbenzene to butene and styrene with high efficiency. Compared with metal oxide-based catalysts, CNTs have enhanced selectivity for alkenes. Although the catalysis of CNTs has been widely investigated, many fundamental issues remain unclear, such as the active site structure, the microscopic reaction mechanism, and the origin of the activity. The aim of this work is to provide deeper insight into surface-modified CNT catalysis. The ODH of propane, which is the

\footnotetext{
* Corresponding author. Tel: +86-21-65643977; Fax: +86-21-55665572; E-mail: knfan@fudan.edu.cn

\#Corresponding author. Tel: +86-21-55664439; Fax: +86-21-55665572; E-mail: lizhenhua@fudan.edu.cn

This work was supported by the National Natural Science Foundation of China $(20973041,21273042)$ and the National Basic Research Program of China (973 Program, 2009CB623506, 2011CB808505).

DOI: 10.1016/S1872-2067(12)60627-5 | http://www.sciencedirect.com/science/journal/18722067 | Chin. J. Catal., Vol. 34, No. 7, July 2013
} 
major component of shale gas [2,9], is studied as a model reaction for ODH of light alkanes using density functional theory (DFT) calculations.

All calculations were carried out using the SIESTA package with the PBE functional [10] in combination with a numerical double- $\zeta$ plus polarization (DZP) basis set and Troullier-Martins norm-conserving pseudopotentials [11,12]. The L-BFGS [13] and Broyden Dimer methods [14,15] were used for locating energy minima and transition states (TSs), respectively, until the Cartesian forces on the relaxed atoms were all less than $0.02 \mathrm{eV} / \AA$. The energy cutoff for the real space grid used to represent the density was set as $150 \mathrm{Ry}$. Spin polarization was considered during all of the calculations.

Experimentally, the surface of CNTs is usually terminated by a variety of oxygenic functional groups (CO groups) because they are always treated by oxygenants before use $[16,17]$. Zhang et al. [18] showed that ketone-type carbonyl groups $(\mathrm{C}=0)$ are possible active sites of CNTs in the ODH of $n$-butane. In the present study, an optimized armchair $(5,5)$ single-walled carbon nanotube (SWNT) (Fig. 1) was selected as the one-dimensional periodic model of the pristine CNT (pr-CNT). Various CO groups were then introduced to pr-CNT and structural defects were constructed in the pr-CNT to mimic possible active sites with different chemical environments (Fig. 1). The structural defects considered are the Stone-Wales defect (o-dsw-CNT), single vacancy (o- $\left.\mathrm{d}_{1}-\mathrm{CNT}\right)$, and multiple vacancies (o- $\mathrm{d}_{3}-\mathrm{CNT}$ and $\left.\mathrm{o}-\mathrm{d}_{4}-\mathrm{CNT}\right)$, which are energetically favorable structures and are detected in experiments [19-24]. For each CNT catalyst model, several possible $\mathrm{CO}$ groups, including ketone $\mathrm{C}=\mathrm{O}$, single-bonded $\mathrm{C}-\mathrm{O}$, and epoxy $\mathrm{COC}$, were investigated and the most stable one of each model was chosen as the catalyst (Fig. 1), where each model contains a pair of $\mathrm{CO}$ groups. In the periodic models, the supercell contained eight carbon layers and the size of the unit cell was $20.00 \AA \times 20.00 \AA$ $\times 19.52 \AA$ with a vacuum separation of greater than $15 \AA$ between slabs. All of the atoms in the periodic slab models were allowed to relax. To simulate the terminal of broken CNTs, we built two cluster models, namely o- $\mathrm{cl}_{1}-\mathrm{CNT}$ and o-cl 2 -CNT (Fig. $1(\mathrm{~b})$ and (c)), with a pair of $\mathrm{C}=0$ groups on the same benzene

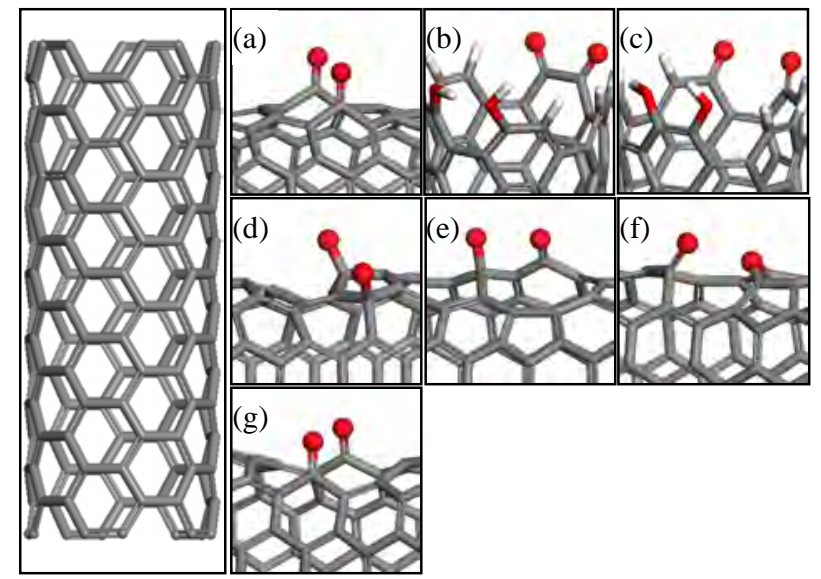

Fig. 1. Optimized structure of 8-layer armchair $(5,5)$ SWNT model and seven oxygen-modified CNT catalyst models. (a) o-pr-CNT; (b) o-cl 1 -CNT; (c) o-cl 2 -CNT; (d) o-dsw-CNT; (e) o-d d $_{1}-\mathrm{CNT}$; (f) o-d ${ }_{3}-\mathrm{CNT}$; (g) o- $\mathrm{d}_{4}-\mathrm{CNT}$. $\mathrm{C}=$ grey, $\mathrm{O}=$ red, and $\mathrm{H}=$ white.

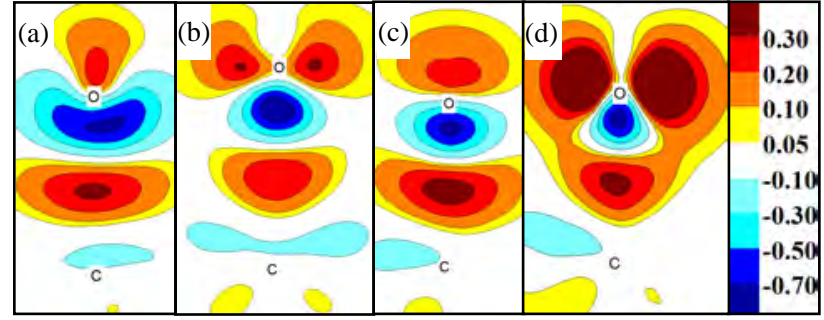

Fig. 2. Contour plots of the total electron charge density difference (unit: e/ $\AA^{3}$ ) constructed by subtracting the total electron densities of CNT with the CO group from the separated $\mathrm{O}$ atom and the rest of CNT.

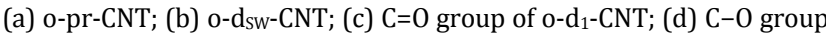
of o-d $\mathrm{d}_{1}-\mathrm{CNT}$.

ring and two adjacent benzene rings, respectively. Both of the o-cl 1 -CNT and o-cl 2 -CNT models contained eight carbon layers with the middle four layers fixed. They were placed in a cubic cell of $a=b=15 \AA$ and $c=35 \AA$.

The bonding between $\mathrm{C}$ and $\mathrm{O}$ in the $\mathrm{CO}$ groups was analyzed by the contour plots of the electron charge density difference (Fig. 2). In general, $\mathrm{C}=0$ groups have a bond length between 1.24 and $1.27 \AA$, while $\mathrm{C}-\mathrm{O}$ groups have a bond length between 1.37 and $1.39 \AA$. The results show that the $\mathrm{C}=0$ group (o-pr-CNT, Fig. 2(a)) and the C-O group (o-dsw-CNT, Fig. 2(b)) have distinctively different bonding characteristics between $\mathrm{C}$ and $\mathrm{O}$, where there is only one electron rich region on the oxygen side of the $\mathrm{C}-\mathrm{O}$ bond but two on the oxygen side of the $\mathrm{C}=\mathrm{O}$ bond. On o-d ${ }_{1}$-CNT (Fig. 2(c) and (d)), which has both types of CO groups, the electron rich regions on the oxygen have a larger volume than the separate groups. The result indicates that the orbitals of the $\mathrm{C}=\mathrm{O}$ and $\mathrm{C}-\mathrm{O}$ groups on $\mathrm{o}-\mathrm{d}_{1}-\mathrm{CNT}$ have a significant influence on each other through conjugation to the CNT $\pi$ orbitals.

Projected density of states (p-DOS) plots (Fig. 3) indicate that the orbitals of the $\mathrm{C}$ atoms in the $\mathrm{C}=0$ groups of o-pr-CNT, $o-\mathrm{cl}_{1}-\mathrm{CNT}, \mathrm{o}-\mathrm{cl}_{2}-\mathrm{CNT}, \mathrm{o}-\mathrm{d}_{3}-\mathrm{CNT}$, and $\mathrm{o}-\mathrm{d}_{4}-\mathrm{CNT}$ are much more localized because almost no states can be found at the Fermi level. In contrast, the orbitals of the $\mathrm{C}$ atom in the $\mathrm{C}-\mathrm{O}$ group of o-dsw-CNT are delocalized with a broad peak across the Fermi

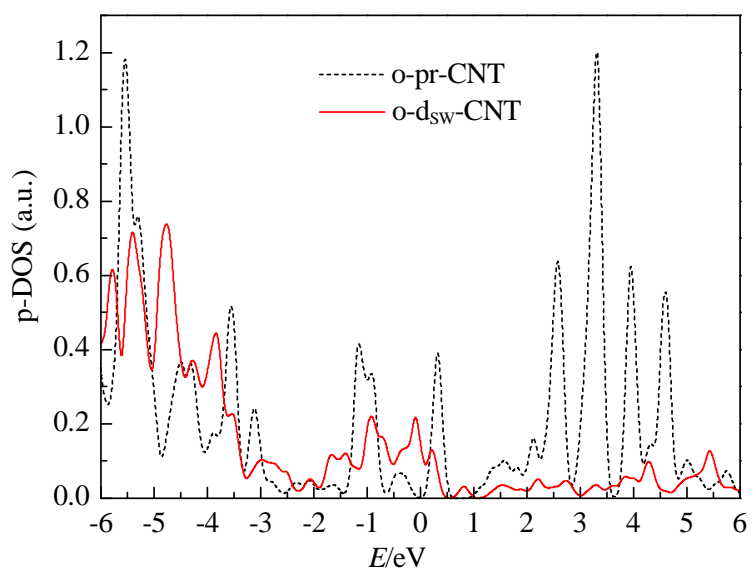

Fig. 3. Projected density of states (p-DOS) of the $\mathrm{C}$ atom of one $\mathrm{CO}$ group in o-pr-CNT and o-dsw-CNT. The zero of the energy axis is chosen as the Fermi level for each model. 


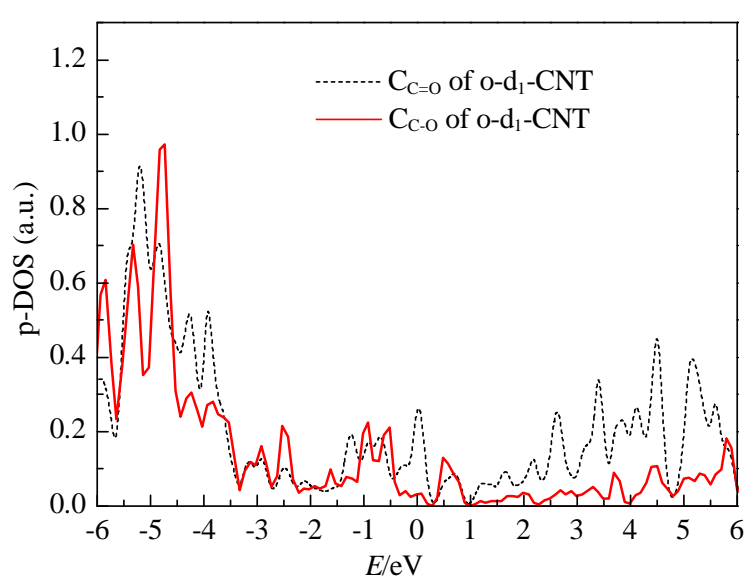

Fig. 4. Projected density of states ( $p-D O S$ ) of the $C$ atom of $C=0$ group and $\mathrm{C}-\mathrm{O}$ group in $\mathrm{o}-\mathrm{d}_{1}-\mathrm{CNT}$. The zero of the energy axis is chosen as the Fermi level for each model.

level, which indicates that the orbitals of these carbons are also part of the CNT $\pi$ orbitals. For $0-d_{1}$-CNT (Fig. 4), the orbitals of the $\mathrm{C}$ atom in the $\mathrm{C}-\mathrm{O}$ group are also delocalized, with a small peak at the Fermi level. It is interesting to see that the orbitals of the $\mathrm{C}$ atom in the $\mathrm{C}=\mathrm{O}$ group of $\mathrm{o}-\mathrm{d}_{1}-\mathrm{CNT}$ are also delocalized with a peak at the Fermi level. This again indicates that the orbitals of the two types of CO bonds in o-d $\mathrm{d}_{1}$-CNT influence each other through conjugation to the CNT $\pi$ orbital, and their electronic structures are different. To analyze the bonding behavior of the CO groups and CNT, we plotted the occupied molecular orbitals (MOs) containing the orbital of the $\mathrm{CO}$ groups for the seven catalysts. We found that the orbitals of the CO groups and the CNT have significant overlap in the MOs, and the orbitals of the carbon atoms are also part of the CNT $\pi$ orbital.

Natural bond orbital (NBO) charge analyses (Table 1) indicate that the $\mathrm{CO}$ groups can be divided into three categories with total charges of about $-0.2,0$, and +0.2 e for the $\mathrm{C}-0, \mathrm{C}=0$, and COC groups, respectively. For o- $\mathrm{d}_{\mathrm{sw}} \mathrm{CNT}$, the charge of $\mathrm{C}$ is +0.18 e while the total charge of the $\mathrm{C}-0$ group is -0.27 e, indicating significant electron transfer from the CNT bulk to the $\mathrm{C}-\mathrm{O}$ group. For the $\mathrm{C}=0$ groups in o-pr-CNT, o- $\mathrm{Cl}_{1}-\mathrm{CNT}$, o-cl $2-C N T, o-d_{3}-C N T, o-d_{4}-C N T$, and o- $\mathrm{d}_{1}-\mathrm{CNT}$, the charge of $\mathrm{C}$ is from +0.38 e to +0.48 e while the total charges of the $\mathrm{C}=0$ groups are close to zero (from -0.06 e to +0.04 e), showing that the charge transfer is mainly localized between the two bonding atoms. For o- $\mathrm{d}_{3}-\mathrm{CNT}$, the total charge of the COC group is +0.19 e, indicating electron transfer from the COC group to the CNT bulk. The results also indicate that the charge of $\mathrm{C}$ is more sensitive to the local structural environment than $\mathrm{O}$. This is not unexpected because the $\mathrm{C}$ atoms in the $\mathrm{CO}$ groups are part of the CNT and their orbitals are conjugated with the CNT $\pi$ orbitals. In fact, a good linear relationship is found between the charge of $\mathrm{C}$ and the total charge of the $\mathrm{CO}$ group. The results indicate that the conjugation between the orbitals of the $\mathrm{CO}$ group and the CNT is the main factor that determines the total charge of the group, where CNT serves as an electron reservoir. Because in $\mathrm{ODH}$ of alkanes $\mathrm{C}-\mathrm{H}$ activation through nucleophilic
Table 1

Natural bond orbital charge analyses of the carbon and oxygen atoms, and the $\mathrm{CO} / \mathrm{COC}$ groups.

\begin{tabular}{|c|c|c|c|c|c|c|}
\hline & $\mathrm{C}(1)$ & $\mathrm{O}(1)$ & $\mathrm{CO}(1)$ & $\mathrm{C}(2)$ & $\mathrm{O}(2)$ & $\mathrm{CO}(2)$ \\
\hline o-pr-CNT & 0.43 & -0.45 & -0.02 & & & \\
\hline o-cl - -CNT & 0.41 & -0.47 & -0.06 & & & \\
\hline $\mathrm{o}-\mathrm{Cl}_{2}-\mathrm{CNT}$ & 0.41 & -0.46 & -0.05 & & & \\
\hline $\mathrm{o}-\mathrm{d}_{3}-\mathrm{CNT}$ & $0.48^{a}$ & -0.45 & 0.04 & $0.65^{\mathrm{b}}$ & -0.46 & 0.19 \\
\hline o- $\mathrm{d}_{4}-\mathrm{CNT}$ & 0.41 & -0.46 & -0.05 & & & \\
\hline o-d $d_{s w}-C N T$ & 0.18 & -0.45 & -0.27 & & & \\
\hline$o-d_{1}-C N T$ & $0.18^{c}$ & -0.38 & -0.20 & $0.38^{\mathrm{d}}$ & -0.43 & -0.05 \\
\hline
\end{tabular}

${ }^{a}$ Charge of the $\mathrm{C}$ atom of the $\mathrm{C}=0$ group in $\mathrm{o}-\mathrm{d}_{3}-\mathrm{CNT}$.

b Total charge of the two $\mathrm{C}$ atoms of the COC group in o- $\mathrm{d}_{3}-\mathrm{CNT}$.

${ }^{\mathrm{c}}$ Charge of the $\mathrm{C}$ atom of the $\mathrm{C}-\mathrm{O}$ group in o- $\mathrm{d}_{1}-\mathrm{CNT}$.

d Charge of the $\mathrm{C}$ atom of the $\mathrm{C}=0$ group in $\mathrm{o}-\mathrm{d}_{1}-\mathrm{CNT}$.

attack of oxygenic functional groups is usually the rate-determining step (RD) [5,25-27], it is expected that the total charge of the CO group will determine the activity of the CO group, and thus conjugation would have a large effect on the ODH of propane on the CNT catalysts. Furthermore, it should be noted that the spin state of the CNT system will also affect its catalytic activity through the conjugation between CNT and CO groups. Khavryuchenko et al. [28] showed that the spin state of the catalyst particle is crucial for the activity and product selectivity of the reaction. The net spins of o- $\mathrm{dsw}_{\mathrm{s}}$-CNT and o-d $\mathrm{d}_{1}-\mathrm{CNT}$ are 1.23 and $1.20 \mu \mathrm{b}$, respectively. Spin population analyses of the two catalysts indicate that the spin density has been redistributed between the two adjacent $\mathrm{CO}$ groups because of conjugation with the CNT $\pi$ orbital. Therefore, conjugation also affects the spin population of the $\mathrm{C}-\mathrm{O}$ groups.

All of the possible reaction pathways on each catalyst model were investigated, and it was found that they are similar. Figure 5 shows two typical potential energy surface (PES) plots of the reaction on oxidized o-pr-CNT and o-dsw-CNT, which are representative of the $\mathrm{C}=\mathrm{O}$ and $\mathrm{C}-\mathrm{O}$ functional groups, respectively. To produce propene, propane will undergo two $\mathrm{C}-\mathrm{H}$ activation steps. $\mathrm{C}-\mathrm{H}$ activation of the methylene group occurs by the $\mathrm{CO}$ group through a radical mechanism [29], resulting in a $\mathrm{C}_{3} \mathrm{H}_{7}$ radical. The $\mathrm{C}_{3} \mathrm{H}_{7}$ radical then either migrates to another $\mathrm{CO}$ group and undergoes a second $\mathrm{C}-\mathrm{H}$ activation by dissociating its methyl hydrogen to oxygen via a radical mechanism to form propene, as shown by $\mathrm{R}-\mathrm{R}$ in Fig. 5 , or the $\mathrm{C}_{3} \mathrm{H}_{7}$ radical can chemically adsorb on the oxygen of another $\mathrm{CO}$ group to form a stable $i$-propoxide intermediate. Starting from $i$-propoxide, cleavage of the $\mathrm{C}-\mathrm{O}$ bond and $\mathrm{H}$ removal from the methyl group by nearby oxygen can take place simultaneously via a concerted mechanism to form propene, as shown by R-C in Fig. 5. After propene desorption, two hydroxyl groups on the surface can form $\mathrm{H}_{2} \mathrm{O}$ by a hydrogen transfer process. The reduced CNT catalyst is then oxidized by dioxygen, which is a fast process in the ODH reactions $[5,30]$. It should be noted that on the oxidized o-pr-CNT there is no concerted mechanism to produce propene from $i$-propoxide. To form propene, $i$-propoxide must regenerate IM1a through TS1b and then form propene via the radical mechanism.

By comparing the PESs of all the CNT catalysts, it can be concluded that for the first $\mathrm{C}-\mathrm{H}$ activation process the activity 


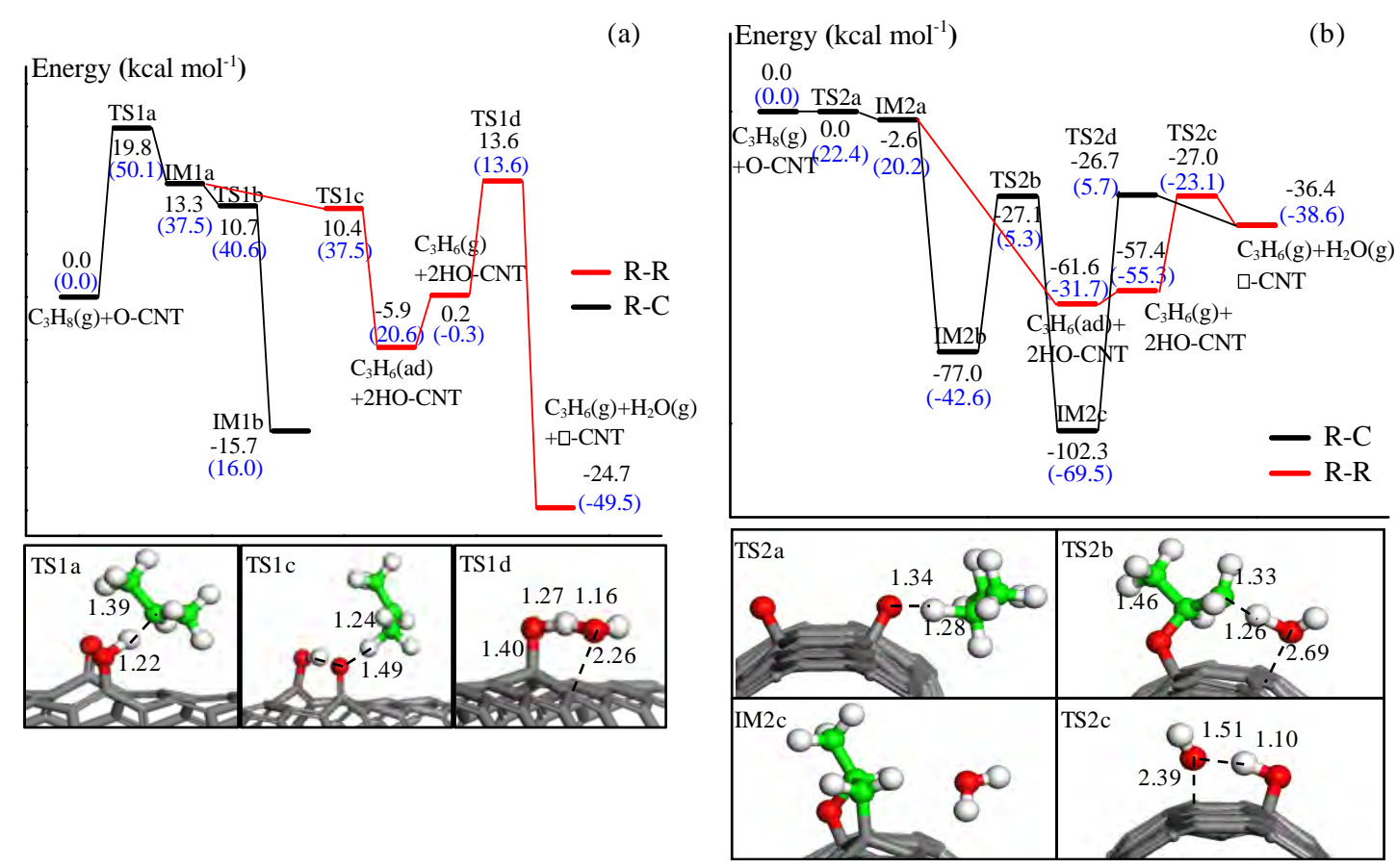

Fig. 5. ZPE-corrected potential energy profiles of the ODH reaction on o-pr-CNT (a) and o-dsw-CNT (b). "R" and "C" represent the radical and concerted mechanism, respectively. Values in parentheses are relative Gibbs free energies at $700 \mathrm{~K}$. The open square $\square$ denotes the oxygen vacancy of the CNT. The energies of TS1b and TS1c become lower than IM1a after the ZPE correction because of the harmonic approximation.

of the $\mathrm{CO}$ groups decrease in the order $\mathrm{C}-\mathrm{O}>\mathrm{C}=\mathrm{O}>\mathrm{COC}$. For the second $\mathrm{C}-\mathrm{H}$ activation process via the radical mechanism, except for $\mathrm{o}-\mathrm{d}_{3}$-CNT the process is almost barrierless. In fact, because of the flatness of the PES on some catalysts, for example o-dsw-CNT, no transition state for this process could be located. Conversely, the second $\mathrm{C}-\mathrm{H}$ activation via the concerted mechanism through $i$-propoxide has to overcome a high energy barrier. Subsequent formation of water also has an energy barrier. Which step is the $\mathrm{RD}$ step depends on the relative rate constants of the three key steps. Taking the Gibbs free energy at the operando temperature of $700 \mathrm{~K}$ into consideration, the first $\mathrm{C}-\mathrm{H}$ activation step is generally the RD step on catalysts with $\mathrm{C}=\mathrm{O}$ and COC groups. It should be noted that on o- $\mathrm{d}_{\mathrm{sw}}-\mathrm{CNT}$ and $\mathrm{o}-\mathrm{d}_{1}$-CNT there is no high energy barrier involved in the R-R pathway. However, because the formation of $i$-propoxide also has no energy barrier, whereas there is very high energy barrier for its conversion to propene via the concerted mechanism, as the reaction progresses all of the surface oxygen sites will be blocked by $i$-propoxide and the catalyst will be poisoned if $i$-propoxide is too stable.

As discussed above, because of the different chemical environments of the $\mathrm{CO}$ groups, the conjugation between their orbitals and the CNT $\pi$ orbital has a significant influence on their total charge, and consequently on their $\mathrm{C}-\mathrm{H}$ activation activities. On o-dsw-CNT, which has the most negative CO group, the energy barrier for the first $\mathrm{C}-\mathrm{H}$ activation is only a few kcal $\mathrm{mol}^{-1}$, but that for the second $\mathrm{C}-\mathrm{H}$ activation is higher than 50 kcal mol-1. Conversely, on $\mathrm{o}-\mathrm{d}_{3}-\mathrm{CNT}$ the COC group has the most positive $\mathrm{CO}$ group, and the energy barrier of the first $\mathrm{C}-\mathrm{H}$ activation step is $60.2 \mathrm{kcal} \mathrm{mol}^{-1}$ and the second $\mathrm{C}-\mathrm{H}$ activation step has to overcome an energy barrier of almost $30 \mathrm{kcal} \mathrm{mol}^{-1}$.
Interestingly, the energy barriers $\left(\Delta E_{\mathrm{e}}^{\#}\right)$ of the first $\mathrm{C}-\mathrm{H}$ activation step and the second $\mathrm{C}-\mathrm{H}$ activation step from $i$-propoxide have an approximately linear relationship with the total charge of the CO group (Fig. 6). This relationship indicates that the catalytic performance of the functional group on CNT can be tuned by tuning the conjugation between the orbitals of the $\mathrm{CO}$ group and the CNT $\pi$ orbital. Although electron withdrawal from CNT increases the activity of the $\mathrm{CO}$ group in the first $\mathrm{C}-\mathrm{H}$ bond activation, it stabilizes formation of the $i$-propoxide intermediate and thus inhibits the formation of propene. The opposite is true for electron donation to CNT. As mentioned above, although the energy barrier for the second $\mathrm{C}-\mathrm{H}$ activa-

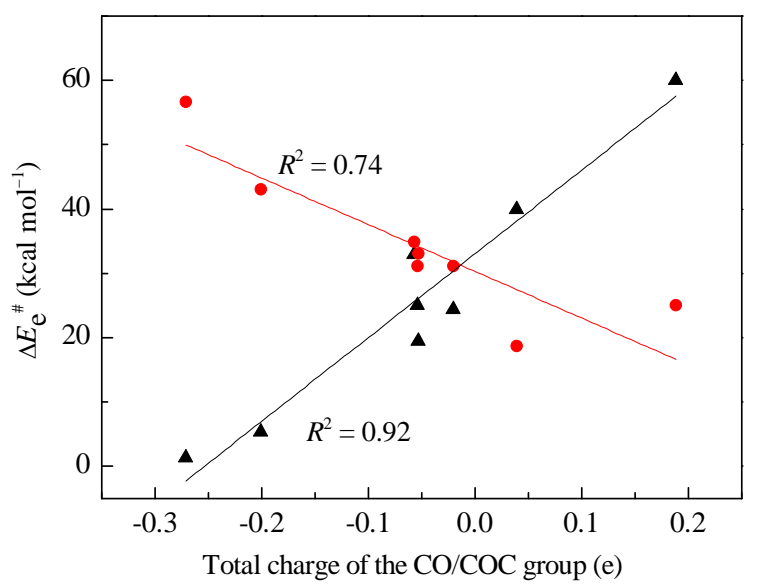

Fig. 6. Correlation between the total charge of the $\mathrm{CO}$ group with the energy barriers $\left(\Delta E_{\mathrm{e}}^{\#}\right)$ of the first $\mathrm{C}-\mathrm{H}$ activation step (triangles) and the propene formation step from $i$-propoxide (cycles). $\Delta E_{\mathrm{e}}^{\#}$ are not ZPE corrected. 
tion step of the R-R mechanism is not high, formation of $i$-propoxide has almost no energy barrier and if $i$-propoxide is too stable this will poison the catalyst. As a result, a balance must be reached between the activities of the two $\mathrm{C}-\mathrm{H}$ activation steps, which is the intersection of the two lines in Fig. 6. The well-known volcano curve can thus be observed for CNT catalysts. For example, on o-pr-CNT, o-cl 1 -CNT, o- $\mathrm{cl}_{2}$-CNT, and $\mathrm{o}-\mathrm{d}_{4}-\mathrm{CNT}$, the total charges of the $\mathrm{CO}$ groups fall in the range from -0.1 to 0 e. In this case, these catalysts show moderate activity for both the first $\mathrm{C}-\mathrm{H}$ activation and the propene formation step. Therefore, the balance can be tuned by tuning the charge on the functional group, which in turn can be realized by tuning the conjugation between the orbitals of the $\mathrm{CO}$ group and CNT, which acts as an electron reservoir.

Experimentally, Liu et al. [31] found that the active sites on CNT and nanodiamond are composed of both $s p^{2-}$ and $s p^{3}$-hybridized carbon atoms. Their results suggest that the activity of the $\mathrm{CO}$ groups with $s p^{2}$-hybridized carbon can be controlled by embedding them into a matrix of highly curved and strained graphitic surface that contains a specific percentage of carbon atoms with $s p^{3}$ hybridization. Moreover, they found that the yield and selectivity of alkane ODH can be greatly improved by decoration with additives and heteroatom functionalities [8,32]. This is in agreement with the current study, where doping with heteroatoms and additives modifies the electronic structure of CNT and changes the activity of the functional group through the conjugation between the orbitals of the functional groups and the CNT $\pi$ orbital.

Although conjugation is the key factor that affects the catalytic performance of CNT, defect size also has subtle effects on the activity of the catalyst. Comparing the PES plots of the reactions on o-pr-CNT, o- $\mathrm{d}_{4}-\mathrm{CNT}$, o-cl ${ }_{1}-\mathrm{CNT}$, and o-cl 2 -CNT, where the latter two can be regarded as large defects, it can be seen that the formation of $\mathrm{H}_{2} \mathrm{O}$ becomes more difficult with increasing defect size. The results also indicate that large defects should be avoided.

In summary, conjugation between the orbitals of the oxygenic functional groups and the CNT $\pi$ orbitals is the key factor that determines the $\mathrm{C}-\mathrm{H}$ activation activity of the functional groups. The bulk CNT serves as the electron reservoir, donating or withdrawing electrons from the functional groups and thus altering their $\mathrm{C}-\mathrm{H}$ activation activity. Groups that withdraw electrons from $\mathrm{CNT}$ have high first $\mathrm{C}-\mathrm{H}$ activation activity but inhibit the second $\mathrm{C}-\mathrm{H}$ activation from $i$-propoxide to form propene, and the $i$-propoxide formed may be so stable as to poison the catalysts. Conversely, groups that donate electrons to CNT have lower $\mathrm{C}-\mathrm{H}$ activation activities but form $i$-propoxide groups that are less stable. The balance between the two $\mathrm{C}-\mathrm{H}$ activation steps can be tuned by tuning the conjugation between the orbitals of the functional groups and CNT to produce optimized catalytic performance of the CNT catalysts.

\section{Acknowledgements}

We are grateful to the High Performance Computer Center of Fudan University for the allocation of computer time.

\section{References}

[1] Cavani F, Ballarini N, Cericola A. Catal Today, 2007, 127:113

[2] Mamedov E A, Corberan V C. Appl Catal A, 1995, 127: 1

[3] Su D S, Zhang J, Frank B, Thomas A, Wang X C, Paraknowitsch J, Schlögl R. ChemSusChem, 2010, 3: 169

[4] Yu D S, Nagelli E, Du F, Dai L M. J Phys Chem Lett, 2010, 1: 2165

[5] Zhang J, Su D S, Zhang A H, Wang D, Schlögl R, Hébert C. Angew Chem, Int Ed, 2007, 46: 7319

[6] Mestl G, Maksimova N I, Keller N, Roddatis V V, Schlögl R. Angew Chem, Int Ed, 2001, 40: 2066

[7] Su D S, Maksimova N, Delgado J J, Keller N, Mestl G, Ledoux M J, Schlögl R. Catal Today, 2005, 102-103: 110

[8] Zhang J, Liu X, Blume R, Zhang A H, Schlögl R, Su D S. Science, 2008, 322: 73

[9] Cavani F, Trifirò F. Catal Today, 1995, 24: 307

[10] Perdew J P, Burke K, Ernzerhof M. Phys Rev Lett, 1996, 77: 3865

[11] Junquera J, Paz O, Sanchez-Portal D, Artacho E. Phys Rev B, 2001, 64: 235111

[12] Troullier N, Martins J L. Phys Rev B, 1991, 43: 1993

[13] Liu D C, Nocedal J. Math Program, 1989, 45: 503

[14] Shang C, Liu Z P.J Chem Theory Comput, 2010, 6: 1136

[15] Henkelman G, Jonsson H. J Chem Phys, 1999, 111: 7010

[16] Boehm H P. Carbon, 1994, 32: 759

[17] Figueiredo J L, Pereira M F R, Freitas M M A, Órfão J J M. Carbon, 1999, 37: 1379

[18] Zhang J, Su D S, Blume R, Schlögl R, Wang R, Yang X G, Gajovic A.

\section{Graphical Abstract}

Chin. J. Catal., 2013, 34: 1291-1296 doi: 10.1016/S1872-2067(12)60627-5

Tuning the catalytic performance of carbon nanotubes by tuning the conjugation between the $\pi$ orbitals of carbon nanotubes and the active oxygenic functional groups

DU Yujue, LI Zhenhua*, FAN Kangnian*

Fudan University

The conjugation between CNT $\pi$ orbitals and the orbitals of functional groups plays a key role in balancing the activity of the two $\mathrm{C}-\mathrm{H}$ activation steps in the propane dehydrogenation reaction.

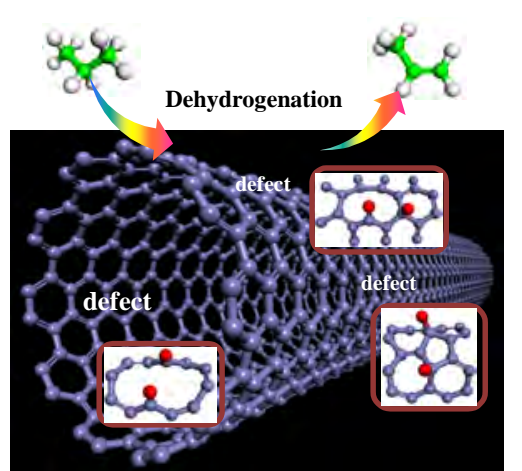


Angew Chem, Int Ed, 2010, 49: 8640

[19] Banhart F, Kotakoski J, Krasheninnikov A V. ACS Nano, 2011, 5: 26

[20] Stone A J, Wales D J. Chem Phys Lett, 1986, 128: 501

[21] Gass M H, Bangert U, Bleloch A L, Wang P, Nair R R, Geim A K. Nat Nanotechnol, 2008, 3: 676

[22] Ugeda M M, Brihuega I, Guinea F, Gomez-Rodriguez J M. Phys Rev Lett, 2010, 104: 096804

[23] Girit C O, Meyer J C, Erni R, Rossell M D, Kisielowski C, Yang L, Park C H, Crommie M F, Cohen M L, Louie S G, Zettl A. Science, 2009, 323: 1705

[24] Meyer J C, Kisielowski C, Erni R, Rossell M D, Crommie M F, Zettl A. Nano Lett, 2008, 8: 3582
[25] Alexopoulos K, Reyniers M F, Marin G B.J Catal, 2012, 289: 127

[26] Fu H, Liu Z P, Li Z H, Wang W N, Fan K N. J Am Chem Soc, 2006, 128: 11114

[27] Dai G L, Liu Z P, Wang W N, Lu J, Fan K N.J Phys Chem C, 2008, 112: 3719

[28] Khavryuchenko O V, Frank B, Trunschke A, Hermann K, Schlögl R. JPhys Chem C, 2013, 117: 6225

[29] Liu Y, Li Z H, Lu J, Fan K N.J Phys Chem C, 2008, 112: 20382

[30] Chen K D, Iglesia E, Bell A T.J Catal, 2000, 192: 197

[31] Liu X, Frank B, Zhang W, Cotter T P, Schlögl R, Su D S. Angew Chem, Int $E d, 2011,50: 3318$

[32] Frank B, Zhang J, Blume R, Schlögl R, Su D S. Angew Chem, Int Ed, 2009, 48: 6913

\title{
通过调变碳纳米管大 $\pi$ 体系与含氧官能团的共轭作用以改变碳纳米管的催化性能
}

\author{
杜钰珏, 李振华\#, 范康年 ${ }^{*}$ \\ 复旦大学化学系, 上海市分子催化与功能材料重点实验室, 上海200433
}

摘要: 选取碳纳米管(CNT)催化剂催化丙烷氧化脱氢作为模型反应, 通过系统研究CNT上多种活性氧位的微观结构, 以及对其电 子结构的表征, 发现通过调控CNT大 $\pi$ 体系与含氧官能团之间的共轭效应可以改变CNT的催化活性. CNT体系充当一个电子存储 器, 通过活性位与CNT的离域效应向活性位提供或夺取电子改变反应活性. 对于丙烷氧化脱氢, 当电子从CNT流向官能团时, 第 一步 C-H断键活性提高, 但反应过程中生成的中间体过于稳定将导致CNT催化剂活性位被占据, 从而抑制第二步 $\mathrm{C}-\mathrm{H}$ 活化生成丙 烯. 反之, 当电子从官能团流向 CNT时, 第一步 $\mathrm{C}-\mathrm{H}$ 断键活性较低, 生成的中间体较不稳定, 较易生成丙烯. 因此, 可以通过调控 CNT与官能团之间的电子共轭效应来平衡两步 $\mathrm{C}-\mathrm{H}$ 键的活化. 这些结果有助于从微观尺度上理解 CNT催化剂活性的来源, 并为 制备高活性CNT催化剂提供理论指导.

关键词：碳纳米管催化剂; 丙烷; 氧化脱氢反应; 密度泛函计算; 共轭效应

收稿日期: 2013-04-30. 接受日期: 2013-05-23. 出版日期: 2013-07-20.

*通讯联系人. 电话: (021)65643977; 传真: (021)55665572; 电子信箱: knfan@fudan.edu.cn

通讯联系人. 电话: (021)55664439; 传真: (021)55665572; 电子信箱: lizhenhua@fudan.edu.cn

基金来源：国家自然科学基金(20973041, 21273042); 国家重点基础研究发展计划(973计划, 2009CB623506, 2011CB808505).

本文的英文电子版由Elsevier出版社在ScienceDirect上出版(http://www.sciencedirect.com/science/journal/18722067). 